\title{
The losses of condensed tannins in six foliar litters vary with gap position and season in an alpine forest
}

\author{
Han $\mathrm{Li}^{(1)}$, Fuzhong $\mathrm{Wu}^{(1-2)}$, \\ Wanqin Yang ${ }^{(1-2)}$, Liya Xu ${ }^{(1)}$, \\ Xiangyin $\mathrm{Ni}^{(1)}$, Jie $\mathrm{He}^{(1)}$, \\ Bo $\operatorname{Tan}^{(1-2)}, \mathrm{Yi} \mathrm{Hu}^{(1)}$, \\ Meta Francis Justin (1)
}

\section{Introduction}

Condensed tannins (CTs) are widely occurring plant polyphenols (Hernes et al. 2001, Hartzfeld et al. 2002) which play a critical role in material cycling and energy flow in forest ecosystems (Schofield et al. 1998, Zhang et al. 2009, Zhou et al. 2012). Because CTs inhibit feeding, their concentration in aboveground plant tissues is proportional to the level of herbivory (De Colmenares et al. 1998, Heil et al. 2002), and it has also been suggested to be a good predictor of litter decomposition (Kraus et al.

\begin{abstract}
Condensed tannins (CTs) have been considered to be intrinsic variables that determine litter decomposition. Forest gaps and the surrounding crown canopies may locally influence the microenvironmental factors, thus affecting the losses of CTs from litter. However, little information is available about the dynamics of CTs loss in forest gaps. In this study, litterbags containing foliar litter of Minjiang fir (Abies faxoniana), red birch (Betula albosinensis), Masters larch (Larix mastersiana), cypress (Sabina saltuaria), Kangding willow (Salix paraplesia), and Lapland azalea (Rhododendron lapponicum), were placed on the forest floor at differet positions from the gap center to the closed canopy in the alpine Minjiang fir forest located in the upper reaches of the Yangtze River and the eastern Tibetan Plateau (China). The samples were retrieved during the periods of snow formation, snow cover, snow melt and in the growing season, and the CTs content was measured at each time point. During the first year, all six types of foliar litter experienced high losses of CTs with values ranging from $70.18 \%$ to $96.67 \%$. Forest gaps accelerated litter CTs losses in the winter but inhibited CTs losses in the growing season, which demonstrated significant seasonal differences. Additionally, the litter of conifers exhibited greater CTs losses in the winter, especially during the snow formation period, whereas the litter of broadleaved trees showed greater CTs losses during the growing season. These results indicate that the predicted reductions in snow depth resulting from future winter warming and the loss of forest gaps due to forest regeneration will inhibit the decomposition of CTs in the litter of alpine forest ecosystems, which will slow soil carbon sequestration from foliar litter in cold biomes.
\end{abstract}

Keywords: Forest Gap, Condensed Tannins, Foliar Litter, Seasonal Snowpack, Alpine Forest

2003, Maie et al. 2008). Litter CTs are rapidly lost in the initial decomposition period due to leaching and chemical modification (Lin et al. 2006, Zhou et al. 2012), but they retard the rate of litter decomposition in the late stage through the formation of recalcitrant complexes resulting from protein and cellulose precipitation, oxidative condensation (Hartzfeld et al. 2002), herbivory inhibition and fungal degradation through toxicity (De Colmenares et al. 1998, Hagerman et al. 1998, Heil et al. 2002). Therefore, the dynamics of CTs loss
(1) Long-term Research Station of Alpine Forest Ecosystems, Institute of Ecology and Forestry, Sichuan Agricultural University, Chengdu 611130 (China); (2) Collaborative Innovation Center of Ecological Security in the Upper Reaches of Yangtze River, Chengdu 611130 (China)

@ Wanqin Yang (scyangwq@163.com)

Received: Jun 10, 2015 - Accepted: May 02, 2016

Citation: Li H, Wu F, Yang W, Xu L, Ni X, He J, Tan B, Hu Y, Justin MF (2016). The losses of condensed tannins in six foliar litters vary with gap position and season in an alpine forest. iForest 9: 910-918. - doi: 10.3832/ifor1738-009 [online 2016-08-04]

Communicated by: Giustino Tonon could be related to the litter decomposition process and could depend on both environmental factors and the initial substrate. Previous studies have primarily focused on determining the structure of CTs and the changes in CTs during the decomposition of the litter of a single species (Sariyildiz 2008, Promis et al. 2012). However, knowledge of the losses of plant litter CTs in alpine forest ecosystems, which might elucidate the process of underground CTs loss, is still limited.

Gap formation by tree fall is a basic forest process altering climate factors and soil organisms, and affecting litter CTs loss in high-altitude forest ecosystems (Whitmore 1989, Spies et al. 1990, Wu et al. 2014a). In winter, the effects of light interception by crown canopies on snow accumulation and the influence of canopy shading on snow ablation could create a snowpack gradient on the forest floor from the gap center to the closed canopy (Wu et al. 2014b). These gradients may vary with the seasons due to the cycles of snow cover freezing and thawing. In deep winter, snowpack depth decreases from the gap center to the closed canopy, which results from interception and deep freezing. Contrastingly, snowpack depth in late winter and early 
spring increases from the gap center to the closed canopy, as its shading prevents the rapid melting of the snow. Additionally, the interception of rainfall and sunlight by the crown canopies in the growing season often affects soil moisture and temperature dynamics (Ritter et al. 2005). Theoretically, the effect of forest gaps on litter CTs loss might vary with both the positions of gaps relative to the crown canopies and the seasons, owing to the different dynamics of leaching, mechanical disruption and biological activities, but little information on the effect of forest gaps and crown canopies on the dynamics of litter CTs loss is available.

There are a variety of mechanisms that can induce significant differences in CTs losses between the gap center and the closed canopy over different decomposition periods. First, some hydrolysable CTs and other easily available nutrients in fresh litter are readily soluble and thus leached immediately (Schofield et al. 1998, Zhang et al. 2009), which results in the rapid loss of CTs in the early period of decomposition, even in winter. Second, during the snow cover and melting periods, the deep snowpack located in the gap center can provide the stable conditions required for degradation and rapid leaching, which result in greater litter CTs losses (Wu et al. 2010, Schofield et al. 1998). However, the loss of CTs is negatively affected by the increased exposure to sunlight and by the more rapid evaporation in the gap center during the growing season (Ritter et al. 2005). In addition, different initial foliar litter substrates may have different effects on the varying degradation characteristics of different species (Batty \& Younger 2007, Song et al. 2008), which could exert a farreaching influence on CTs losses. Previous studies have primarily focused on the loss of mass, the release of nutrients and the changes in degradation during litter decomposition in alpine forests in winter ( Wu et al. 2010, 2014b, Tan et al. 2011a, 2011b, Zhu et al. 2012, 2013, He et al. 2015), but little information is available on the dynamics of litter CTs losses. Therefore, based on previous studies, we hypothesized that (1) litter CTs will be more variable under the stable microenvironments caused by deep snow cover in the gap center during winter, as well as under the suitable moisture and temperature conditions under closed canopies throughout the growing season; (2) the litter CTs losses will continue throughout the first year of this litter decomposition study, resulting in greater losses in winter.

We conducted a one-year field experiment to evaluate the loss of CTs from the foliar litter of an alpine forest located in the upper reaches of the Yangtze River and the eastern Tibetan Plateau (China). Six types of foliar litter were used, spanning a wide range of litter quality charateristics and including both conifers and broadleaved trees. Forest gaps and the associated crown canopies create winter snowpack gradient and freeze-thaw cycles in winter and redistribute precipitation, temperature and solar radiation during the growing season (Wu et al. 2010, 2014a, 2014b, He et al. 2015). Previous studies conducted by our team investigated the litter decomposition dynamics in alpine forests, including the loss of mass, release of nutrients, response of humification and effects on microbial biomass, and we concluded that the deep snow patches caused by forest gaps promoted litter decomposition during winter (Tan et al. 2011a, 2011b, Zhu et al. 2013, $\mathrm{Ni}$ et al. 2014, 2015, Wu et al. $2014 b)$. Based on these results, we measured the litter CTs content and losses during different decomposition periods from the gap center to the closed canopy. The results are expected to characterize the effects of forest gaps on CTs losses from different types of foliar litter during litter decomposition in winter and the growing season, as well as to provide new information on material cycling in alpine forest ecosystems.

\section{Materials and methods}

\section{Site description}

This study was conducted at the Miyaluo Nature Reserve $\left(102^{\circ} 53^{\prime}-102^{\circ} 57^{\prime} \mathrm{E}, 31^{\circ} 14^{\prime}\right.$ $31^{\circ} 19^{\prime} \mathrm{N}, 2458-4619 \mathrm{~m}$ a.s.l.), which is lo- cated in Li County of Sichuan Province, Southwest China. It is a transitional area located in the upper reaches of the Yangtze River and the eastern Tibetan Plateau (Zhu et al. 2013). The annual mean temperature of the study site is $2.7^{\circ} \mathrm{C}$ with mean temperatures of $-8.7{ }^{\circ} \mathrm{C}$ and $9.5^{\circ} \mathrm{C}$ in January and July, respectively, and the annual mean precipitation is $850 \mathrm{~mm}$. The freeze-thaw season generally extends from late October to late April, with a maximum snow depth of approximately $50 \mathrm{~cm}$ and a freeze-thaw cycle time of approximately 120 days (Tan et al. 2010). The tree canopy is dominated by Minjiang fir (Abies faxoniana), red birch (Betula albosinensis), Masters larch (Larix mastersiana) and cypress (Sabina saltuaria), while the most common shrubs in the understory are Kangding willow (Salix paraplesia), Lapland azalea (Rhododendron lapponicum), Berberis sargentiana, Sorbus rufopilosa, and Hippophae rhamnoides. The herbs are dominated by Cacalia spp., Cystopteris montana and a variety of mosses (Wu et al. 2014b, Ni et al. 2015).

\section{Experimental design}

The foliar litter decomposition was studied using the nylon mesh bag technique (O'Connell 1997). In early October 2012, freshly senesced leaves of cypress, Minjiang fir, Masters larch, red birch, Kangding willow and Lapland azalea were collected from the floor of the study site; decayed and weak leaves were excluded. Samples of air-dried litter (10 g per bag) were placed in prepared nylon bags $(20 \times 25 \mathrm{~cm}$ in size, with mesh of $1.0 \mathrm{~mm}$ on top and $0.5 \mathrm{~mm}$ on the bottom). The chemical characteristics (CTs, C, N, P, lignin, cellulose, C/N, C/P, N/P, lignin/ $N$ ) of the six types of initial litter substrate were analyzed (Tab. 1).

Based on the field investigation and previous locally-collected data, three forest gaps greater than $25 \times 25 \mathrm{~m}$ with similar canopy densities were randomly selected within a representative Minjiang fir forest nature reserve $\left(31^{\circ} 14^{\prime} \mathrm{N}, 102^{\circ} 53^{\prime} \mathrm{E}, 3579\right.$ $3582 \mathrm{~m}$ ). Four experimental positions were evenly distributed within each gap from the gap center to the closed canopy (gap center, canopy gap, expanded gap, and

Tab. 1 - Initial quality (\%) of the six types of foliar litter (cypress, Minjiang fir, Masters larch, red birch, Kangding willow, Lapland azalea) in an alpine Minjiang fir alpine forest (mean $\pm S D, n=3)$. Different lowercase letters indicate a significant difference $(P<0.05)$ between species within the same variable (one-way ANOVA).

\begin{tabular}{|c|c|c|c|c|c|c|c|c|c|c|}
\hline Species & $\begin{array}{l}\text { CTs } \\
\text { (\%) }\end{array}$ & $\begin{array}{c}C \\
(\%)\end{array}$ & $\begin{array}{c}N \\
(\%)\end{array}$ & $\begin{array}{l}P \\
\text { (\%) }\end{array}$ & $\begin{array}{l}\text { Lignin } \\
(\%)\end{array}$ & $\begin{array}{l}\text { Cel } \\
\text { (\%) }\end{array}$ & $\mathrm{C} / \mathrm{N}$ & $\mathrm{C} / \mathrm{P}$ & N/P & Lignin/N \\
\hline Cypress & $\begin{array}{c}3.45 \\
\pm 0.06^{\mathrm{b}}\end{array}$ & $\begin{array}{c}51.64 \\
\pm 1.77 \mathrm{bc}\end{array}$ & $\begin{array}{c}0.88 \\
\pm 0.01 \text { b }\end{array}$ & $\begin{array}{r}0.12 \\
\pm 0.01 \mathrm{~cd}\end{array}$ & $\begin{array}{c}14.07 \\
\pm 0.74 \text { b }\end{array}$ & $\begin{array}{c}12.22 \\
\pm 0.38^{\text {a }}\end{array}$ & $\begin{array}{c}58.86 \\
\pm 2.21 \text { b }\end{array}$ & $\begin{array}{c}416.02 \\
\pm 14.04^{\text {a }}\end{array}$ & $\begin{aligned} & 7.08 \\
\pm & 0.41 \text { ab }\end{aligned}$ & $\begin{array}{c}16.04 \\
\pm 1.01^{\text {a }}\end{array}$ \\
\hline Minjiang fir & $\begin{array}{c}12.20 \\
\pm 0.39^{c}\end{array}$ & $\begin{array}{c}50.56 \\
\pm 2.96^{b}\end{array}$ & $\begin{aligned} & 0.88 \\
\pm & 0.01 \text { b }\end{aligned}$ & $\begin{aligned} & 0.11 \\
\pm & 0.01 b c\end{aligned}$ & $\begin{array}{l}15.85 \\
\pm 0.36^{\mathrm{b}}\end{array}$ & $\begin{array}{c}12.19 \\
\pm 0.20^{b}\end{array}$ & $\begin{array}{c}57.77 \\
\pm 3.53^{b}\end{array}$ & $\begin{array}{r}443.51 \\
\pm 36.69\end{array}$ & $\begin{aligned} & 7.68 \\
\pm & 0.72 \mathrm{~b}\end{aligned}$ & $\begin{array}{c}18.11 \\
\pm 0.42^{\circ}\end{array}$ \\
\hline $\begin{array}{l}\text { Masters } \\
\text { larch }\end{array}$ & $\begin{aligned} & 3.08 \\
\pm & 0.06^{b}\end{aligned}$ & $\begin{array}{c}54.35 \\
\pm 0.63^{c}\end{array}$ & $\begin{array}{c}0.86 \\
\pm \\
\end{array}$ & $\begin{array}{r}0.13 \\
\pm 0.01 \mathrm{~d}\end{array}$ & $\begin{array}{c}27.21^{\mathrm{d}} \\
\pm 2.21^{\mathrm{d}}\end{array}$ & $\begin{array}{l}16.45 \\
\pm 0.44^{\mathrm{d}}\end{array}$ & $\begin{array}{c}63.32 \\
\pm 3.49^{b}\end{array}$ & $\begin{array}{l}407.08 \\
\pm 2.42^{\mathrm{a}}\end{array}$ & $\begin{aligned} & 6.44 \\
\pm & 0.38^{a}\end{aligned}$ & $\begin{array}{c}25.95 \\
\pm 1.08^{c}\end{array}$ \\
\hline Red birch & $\begin{aligned} & 0.28 \\
\pm & 0.02{ }^{a}\end{aligned}$ & $\begin{array}{r}49.69 \\
\pm 1.45^{b}\end{array}$ & $\begin{array}{r}1.33 \\
\pm 0.02^{d}\end{array}$ & $\begin{array}{r}0.09 \\
\pm 0.01^{a}\end{array}$ & $\begin{array}{c}36.68 \\
\pm 0.62^{b}\end{array}$ & $\begin{array}{c}12.47 \\
\pm 0.38^{\mathrm{e}}\end{array}$ & $\begin{array}{c}37.24 \\
\pm 1.35^{\text {a }}\end{array}$ & $\begin{array}{c}544.94 \\
\pm 31.72^{c}\end{array}$ & $\begin{array}{c}14.63 \\
\pm 0.36^{d}\end{array}$ & $\begin{array}{c}25.99 \\
\pm 0.37^{c}\end{array}$ \\
\hline $\begin{array}{l}\text { Kangding } \\
\text { willow }\end{array}$ & $\begin{array}{c}0.23 \\
\pm 0.01 \text { a }\end{array}$ & $\begin{array}{c}45.23 \\
\pm 1.65^{a}\end{array}$ & $\begin{array}{r}1.15 \\
\pm 0.03^{c}\end{array}$ & $\begin{aligned} & 0.11 \\
\pm & 0.00^{\mathrm{b}}\end{aligned}$ & $\begin{array}{l}20.22 \\
\pm 0.22{ }^{a}\end{array}$ & $\begin{array}{c}10.45 \\
\pm 0.59 \text { a }\end{array}$ & $\begin{array}{r}39.49 \\
\pm 20.18^{a}\end{array}$ & $\begin{array}{c}408.12 \\
\pm 16.89^{a}\end{array}$ & $\begin{array}{c}10.34 \\
\pm 0.18^{c}\end{array}$ & $\begin{array}{r}17.66 \\
\pm 0.63^{\circ}\end{array}$ \\
\hline $\begin{array}{l}\text { Lapland } \\
\text { azalea }\end{array}$ & $\begin{array}{r}22.49 \\
\pm 1.13^{\mathrm{d}}\end{array}$ & $\begin{array}{c}50.29 \\
\pm 1.60^{\mathrm{b}}\end{array}$ & $\begin{array}{r}0.67 \\
\pm 0.02{ }^{a} \\
\end{array}$ & $\begin{array}{c}0.11 \\
+0.01^{\circ}\end{array}$ & $\begin{array}{r}20.81 \\
\pm 0.18^{c}\end{array}$ & $\begin{array}{r}14.07 \\
\pm 0.41^{c}\end{array}$ & $\begin{array}{r}75.54 \\
\pm 40.47^{c}\end{array}$ & $\begin{array}{c}471.14 \\
\pm 42.04 \mathrm{~b}\end{array}$ & $\begin{array}{r}6.25 \\
\pm 0.25 \text { a }\end{array}$ & $\begin{array}{r}31.24 \\
\pm 0.69^{d}\end{array}$ \\
\hline
\end{tabular}


Fig. 1 - Daily mean air and soil surface temperature of four gap positions (gap center, canopy gap, expanded gap, closed gap) during the first year of litter decomposition year in an alpine Minjiang fir forest (from November 15, 2012 to October 30, 2013). The light grey region indicates the freeze-thaw season (from November 15, 2012 to April 24, 2013- $n=6$ ).

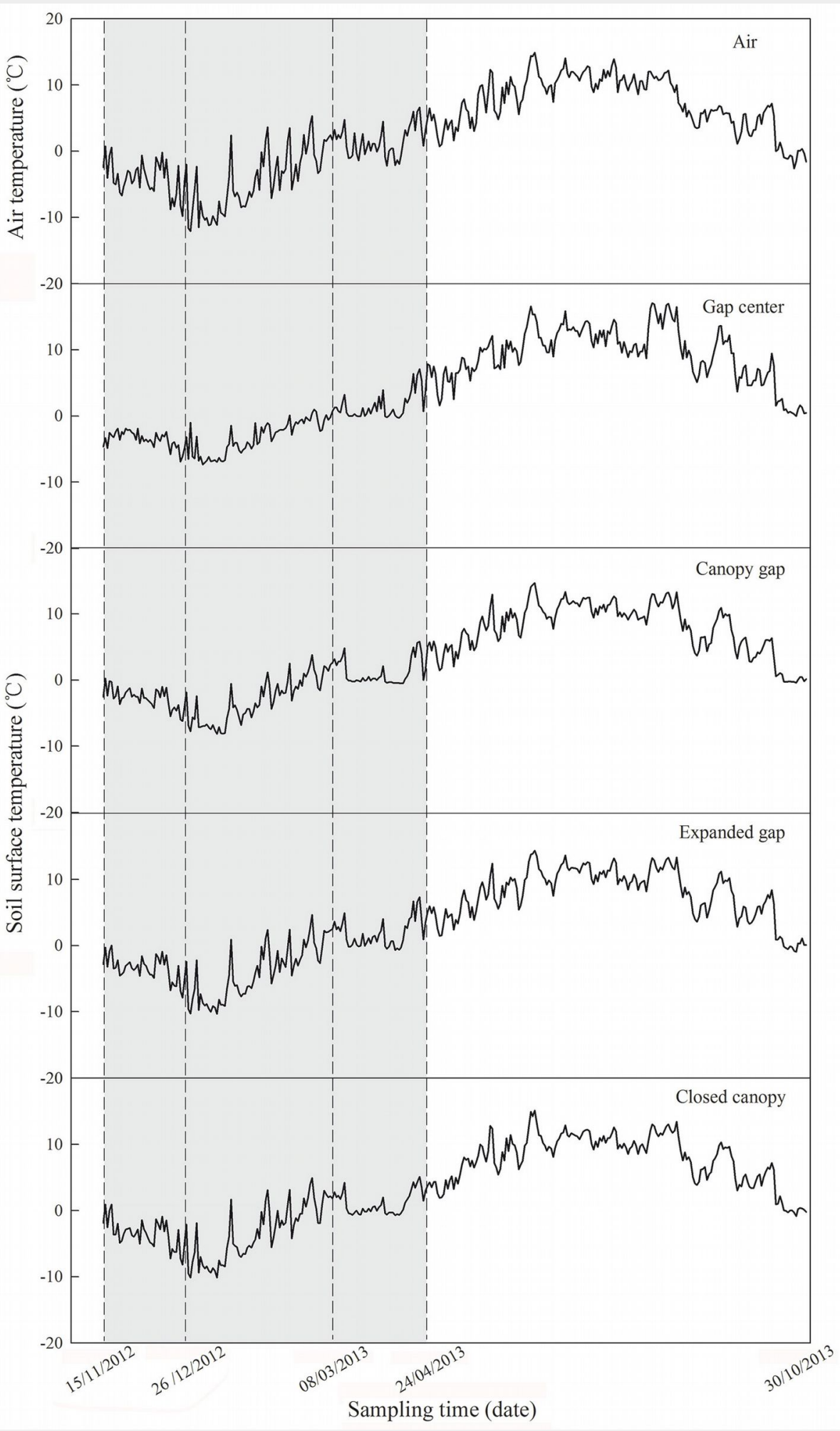

closed canopy), and four $2 \times 2$-m sampling blocks for the six litter species were established in each position at 2-m intervals to ensure adequate sampling of heterogeneous micro-environmental conditions. A total of 864 litterbags $(3$ gaps $\times 4$ positions $\times 6$ species $\times 4$ sampling dates $\times 3$ replicates) were placed on the forest floor from the gap center to the closed canopy on November 15, 2012. The temperature in the litterbags was measured every 2-hours using iButton recorders (iButton DS1923-
F5, Maxim/Dallas Semiconductor, Sunnyvale, CA, USA) placed in two litterbags in each gap position. The air temperature and the temperature in the litterbags from November 15, 2012 to October 30, 2013 are displayed in Fig. 1. The values of the following factors were calculated to clearly describe the temperature characteristics: daily mean temperature (DMT), positive accumulated temperature (PAT, sum of temperatures above $0{ }^{\circ} \mathrm{C}$ ), negative accumulated temperature (NAT, sum of temperatures below $0{ }^{\circ} \mathrm{C}$ - He et al. 2015, Ni et al. 2014, 2015) and the frequency of soil freeze-thaw cycles (FSFC, the total number of times the temperature changed from above/below 0 ${ }^{\circ} \mathrm{C}$ to below/above $0{ }^{\circ} \mathrm{C}$ in a 3 -hour period, Konestabo et al. 2007 - Tab. 2).

To quantify the CTs contents in the litter at different critical periods, which were identified based on the Olsson's division of cold season periods (Olsson et al. 2003) and the field investigations from our previous studies (Zhu et al. 2013, Wu et al. 
Tab. 2 - Characteristics of the daily mean temperature (DMT, ${ }^{\circ} \mathrm{C}$ ), positive accumulated temperature (PAT, ${ }^{\circ} \mathrm{C}$ ), negative accumulated temperature (NAT, ${ }^{\circ} \mathrm{C}$ ) and frequency of soil freeze-thaw cycles (FSFC, times) across each decomposition period of the four gap positions (gap center, canopy gap, expanded gap, closed gap) over the first year of litter decomposition in an alpine Minjiang fir forest.

\begin{tabular}{|c|c|c|c|c|c|c|c|}
\hline Gap Position & $\begin{array}{l}\text { Temp. } \\
\text { Variable }\end{array}$ & $\begin{array}{l}\text { Snow } \\
\text { Formation } \\
\text { Stage }\end{array}$ & $\begin{array}{c}\text { Snow Cover } \\
\text { Stage }\end{array}$ & $\begin{array}{l}\text { Snow Melt } \\
\text { Stage }\end{array}$ & $\begin{array}{c}\text { All } \\
\text { winter }\end{array}$ & $\begin{array}{l}\text { Growing } \\
\text { season }\end{array}$ & 1st year \\
\hline \multirow[t]{4}{*}{ Gap center } & DMT & -3.97 & -3.97 & 2.14 & -1.97 & 9.62 & 4.11 \\
\hline & PAT & 378.47 & 1004.85 & 1604.30 & 2987.62 & 20713.40 & 23701.02 \\
\hline & NAT & -2296.28 & -4433.95 & -482.58 & -7212.81 & -217.40 & -7430.21 \\
\hline & FSFC & 43 & 75 & 54 & 172 & - & 172 \\
\hline \multirow[t]{4}{*}{ Canopy gap } & DMT & -2.90 & -3.25 & 1.13 & -1.77 & 7.81 & 3.43 \\
\hline & PAT & 408.92 & 1066.50 & 922.70 & 2398.12 & 17454.67 & 19853.79 \\
\hline & NAT & -1799.92 & -3875.67 & -287.33 & -5962.92 & -98.00 & -6061.92 \\
\hline & FSFC & 56 & 100 & 29 & 185 & - & 185 \\
\hline \multirow[t]{4}{*}{ Expanded gap } & DMT & -3.46 & -4.15 & 1.82 & -2.22 & 7.87 & 3.26 \\
\hline & PAT & 356.75 & 1039.04 & 1418.50 & 2814.29 & 17971.93 & 20786.22 \\
\hline & NAT & -2017.08 & -4624.67 & -391.25 & -7033.00 & -140.25 & -7173.25 \\
\hline & FSFC & 50 & 92 & 49 & 191 & - & 191 \\
\hline \multirow[t]{4}{*}{ Closed canopy } & DMT & -3.54 & -3.67 & 1.24 & -2.15 & 7.79 & 3.29 \\
\hline & PAT & 448.50 & 1328.92 & 1005.50 & 2782.92 & 17598.58 & 20382.50 \\
\hline & NAT & -2149.17 & -4501.00 & -305.08 & -6955.25 & -61.89 & -7017.14 \\
\hline & FSFC & 59 & 105 & 38 & 201 & - & 201 \\
\hline
\end{tabular}

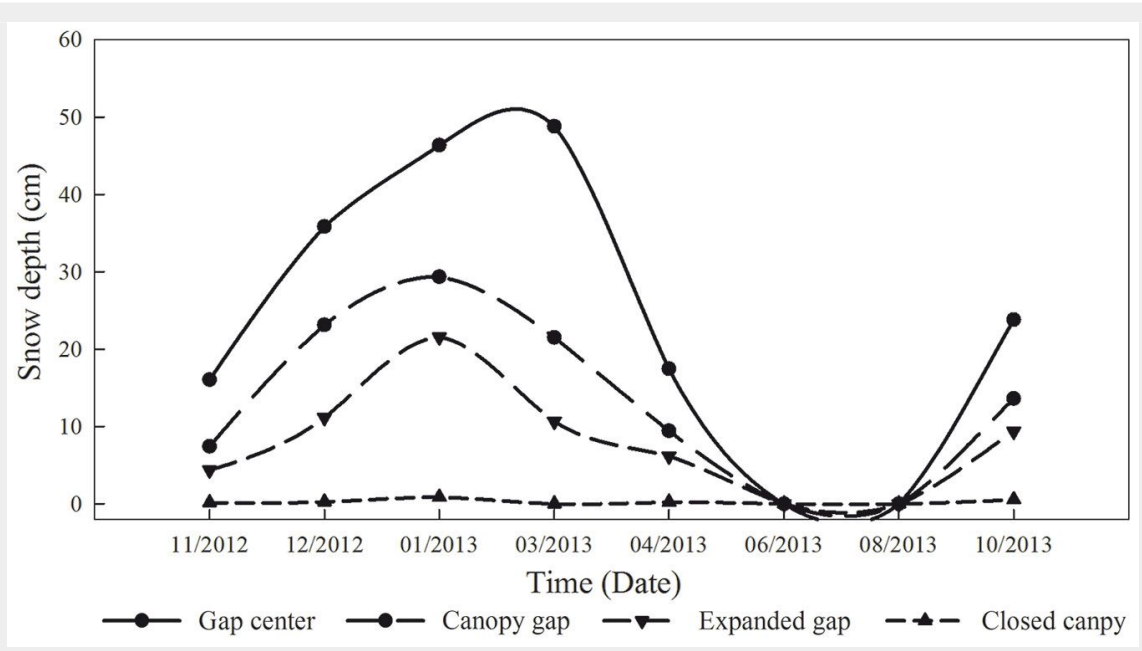

Fig. 2 - Snow depth ( $\mathrm{cm}$ ) at the four gap positions (gap center, canopy gap, expanded gap, closed canopy) during the first year of litter decomposition in an alpine Minjiang fir forest $(n=3)$.

2014b, Ni et al. 2015), we sampled the litterbags on 26 December 2012 (snow formation period, SFP - 41 days after the beginning of the experiment), 8 March 2013 (snow cover period, SCP - 72 days), 24 April 2013 (snow melt period, SMP - 47 days), and 30 October 2013 (growing season, GS - 189 days). Arthropods and for-

eign roots were removed, and the litterbags were returned to the lab for analysis. The depth of the snow cover was measured with a ruler at multiple points in each sampling date (Fig. 2).

\section{Analyses and calculations}

After the roots and foreign materials

Tab. 3 - Results of the repeated measures ANOVA for the effects of period, gap position and species on litter condensed tannins loss (\%) over the first year of litter decomposition in the alpine Minjiang fir forest $(n=72)$.

\begin{tabular}{lrrc}
\hline $\begin{array}{l}\text { Source of } \\
\text { variance }\end{array}$ & df & $F$-value & $P$-value \\
\hline Period $(P)$ & 3 & 68.447 & 0.000 \\
Gap position $(G)$ & 3 & 1.232 & 0.308 \\
Species $(S)$ & 5 & 50.829 & 0.000 \\
P G & 9 & 13.930 & 0.000 \\
$P \times S$ & 15 & 28.906 & 0.000 \\
G $\times S$ & 15 & 3.592 & 0.000 \\
$P \times G \times S$ & 45 & 9.289 & 0.000 \\
\hline
\end{tabular}

were removed, the remaining litter was collected from the litterbags, and ovendried at $65^{\circ} \mathrm{C}$ for at least 48 hours to a constant weight. Samples were then very finely ground with a mill and passed through a $0.3-\mathrm{mm}$ mesh. A conventional vanillin- $\mathrm{HCl}$ assay method was used to measure the CTs in the six types of foliar litter (Hagerman \& Butler 1989). A sample of foliar litter (200 \pm $50 \mathrm{mg}$ ) was extracted with $5 \mathrm{ml}$ of $70 \%$ methanol, maintained at room temperature for 24 hours and then centrifuged at 4 ${ }^{\circ} \mathrm{C}$ and $5000 \mathrm{r} \mathrm{min}^{-1}$ for 10 minutes. Next, 3 $\mathrm{ml}$ of a $4 \%$ vanillin methanol solution and $1.5 \mathrm{ml}$ of $\mathrm{HCl}$ were added to $0.5 \mathrm{ml}$ of the supernatant liquid; the solution was mixed well and reacted in a water bath at $20 \pm 2{ }^{\circ} \mathrm{C}$ for 30 minutes, and the absorbance was measured at $510 \mathrm{~nm}$. Catechin was used as a standard sample to draw the standard curve to calculate the extracted CTs content. All of the analyses were performed in triplicate. The loss of litter mass (Baptist et al. 2010) and CTs (Talbot et al. 2012) over time were calculated as follows (eqn. 1, eqn. 2):

$$
\begin{gathered}
\operatorname{Mass} \operatorname{loss}(\%)=\frac{\left(M_{0}-M_{t}\right)}{M_{0}} \cdot 100 \\
C T \operatorname{Coss}(\%)=\frac{\left(M_{t-1} C_{t-1}\right)-\left(M_{t} C_{t}\right)}{M_{0} C_{0}} 100
\end{gathered}
$$

where $M_{\mathrm{t}}$ and $M_{\mathrm{t}-1}$ represent the remaining litter dry mass between the current $(t)$ and previous ( $t-1)$ sampling dates, respectively; $C_{\mathrm{t}}$ and $C_{\mathrm{t}-1}$ represent the CTs content (\%) between the current and previous sampling dates, respectively; $M_{0}$ and $C_{0}$ are the initial litter dry mass and CTs content, respectively.

\section{Statistical analyses}

Differences in the initial substrate qualities, litter mass losses, CTs contents and CTs losses in the six types of foliar litter for each decomposition period among the four gap positions were evaluated using one-way ANOVA (analysis of variance) and 
LSD (least significant difference) test with $a=0.05$. The effects of the gap positions, species and decomposition period on the loss of CTs were analyzed using a repeated measures ANOVA (Tab. 3). The influence of environmental factors (DMT, PAT, NAT, FSFC) and the initial substrate qualities (initial CTs, C, initial N, initial P, initial cellulose, initial lignin, initial $C / N$, initial $C / P$, initial $N / P$, initial lignin/ $\mathrm{N}$, initial cellulose/lignin) on the loss of CTs at each decomposition period were screened through a step-wise (backward) regression analysis (Tab. 4 - Ni et al. 2015). All of the statistical analyses were performed using the software package SPSS for Windows v. 17.0 (SPSS Inc., IL, USA). The data for all of the tests conformed to a normal distribution.

\section{Results}

\section{Litter condensed tannins content}

The initial CTs content was significantly higher in the conifers compared with the broadleaved trees, with the exception of Lapland azalea which had the highest initial CTs content (Tab. 1). Throughout the first year of this study, the CTs content of all six types of foliar litter decreased and eventually reached low levels $(<4 \%)$ in the growing season (Fig. 3), especially the CTs of the Lapland azalea and Minjiang fir litter, which declined by $18.51 \%$ and $11.51 \%$, respectively.

Tab. 4 - Determination coefficients $\left(R^{2}\right)$ and dominant factors (in parenthesis) of the step-wise regression analysis of litter condensed tannins loss, effected by environmental factors. (DMT): daily mean temperature; (PAT): positive accumulated temperature; (NAT): negative accumulated temperature; (FSFC): frequency of soil freezethaw cycles) and substrate qualities (Initial CTs/C/N/P..., initial quality of the foliar litter) at each decomposition period in the first year of litter decomposition in the alpine Minjiang fir forest. (CTs): condensed tannins; (Lig): lignin; (Cel): cellulose.

\begin{tabular}{lcccccc}
\hline Parameter & $\begin{array}{c}\text { Snow Forma- } \\
\text { tion Stage }\end{array}$ & $\begin{array}{c}\text { Snow Cover } \\
\text { Stage }\end{array}$ & $\begin{array}{c}\text { Snow Melt } \\
\text { Stage }\end{array}$ & $\begin{array}{c}\text { All of } \\
\text { winter }\end{array}$ & $\begin{array}{c}\text { Growing } \\
\text { Season }\end{array}$ & 1st year \\
\hline DMT & - & $0.219(2)$ & - & - & - & - \\
PAT & $0.636(4)$ & - & - & - & - & - \\
NAT & - & - & - & - & - & - \\
FSFC & $0.608(3)$ & - & - & - & - & - \\
Initial CTs & - & - & - & $0.712(4)$ & - & - \\
Initial C & - & - & $0.107(1)$ & - & $0.211(1)$ & - \\
Initial N & $0.312(1)$ & - & - & - & - & - \\
Initial P & - & $0.112(1)$ & - & $0.405(1)$ & - & - \\
Initial Lig & $0.511(2)$ & - & - & $0.561(2)$ & - & - \\
Initial Cel & - & - & - & - & - & $0.631(3)$ \\
Initial C/N & - & - & - & - & - & - \\
Initial C/P & - & - & - & - & - & - \\
Initial N/P & - & - & - & $0.678(3)$ & - & $0.525(1)$ \\
Initial Lig/N & - & - & - & - & $0.355(2)$ & $0.606(2)$ \\
\hline
\end{tabular}

\section{Litter condensed tannins loss}

As shown in Tab. 3, litter CTs loss was considerably affected by sampling time, gap position, species and the interaction of these factors. Over the first year of decomposition, the litters exhibited an overall mass loss of $18.73 \%$ to $46.80 \%$, varying by species (Fig. 4); all six types of foliar litter exhibited significant CTs losses in the range of $70.18 \%$ to $96.57 \%$ of the initial values depending on the species (Fig. 5). The conifers showed a greater loss of CTs $(92.87 \%$ to $96.57 \%$ ) than broadleaved trees ( $70.18 \%$ to $85.98 \%$ ), thus the initial substrate quality of the litter could be a major factors affecting CTs loss (Tab. 4). Additionally, a substantial loss of CTs from both conifers and broadleaved trees occurred both in winter

Fig. 3 - Condensed tannins content (\%) of the six types of foliar litter (cypress, Minjiang fir, Masters larch, red birch, Kangding willow, Lapland azalea) at the four gap positions (gap center, canopy gap, expanded gap, closed canopy) at each sampling time over the first year of litter decomposition in an alpine Minjiang fir forest. Different lowercase letters indicate significant differences $(P<0.05)$ between different gap positions for the same sampling time (mean $\pm S E, n=3$ ).

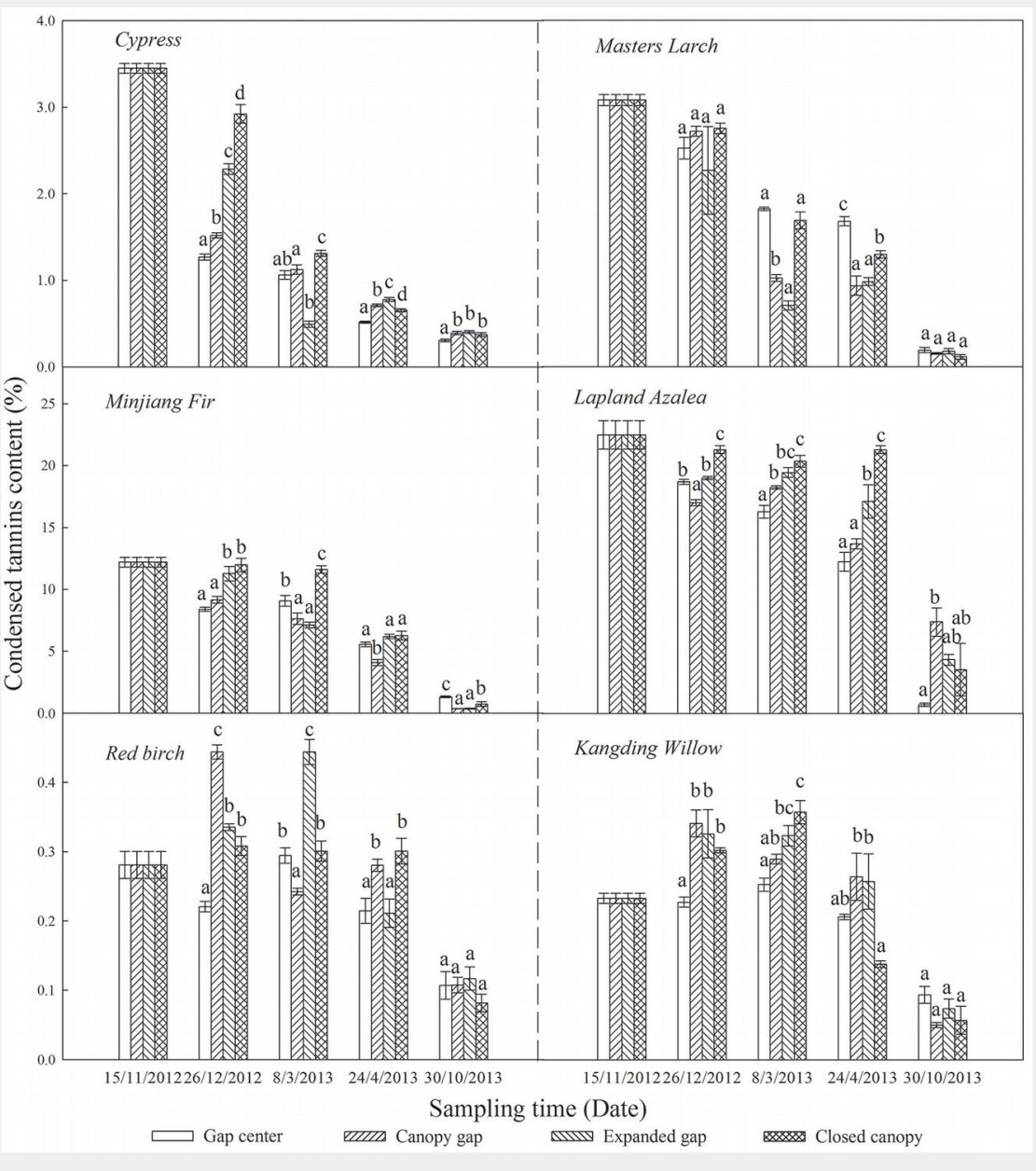




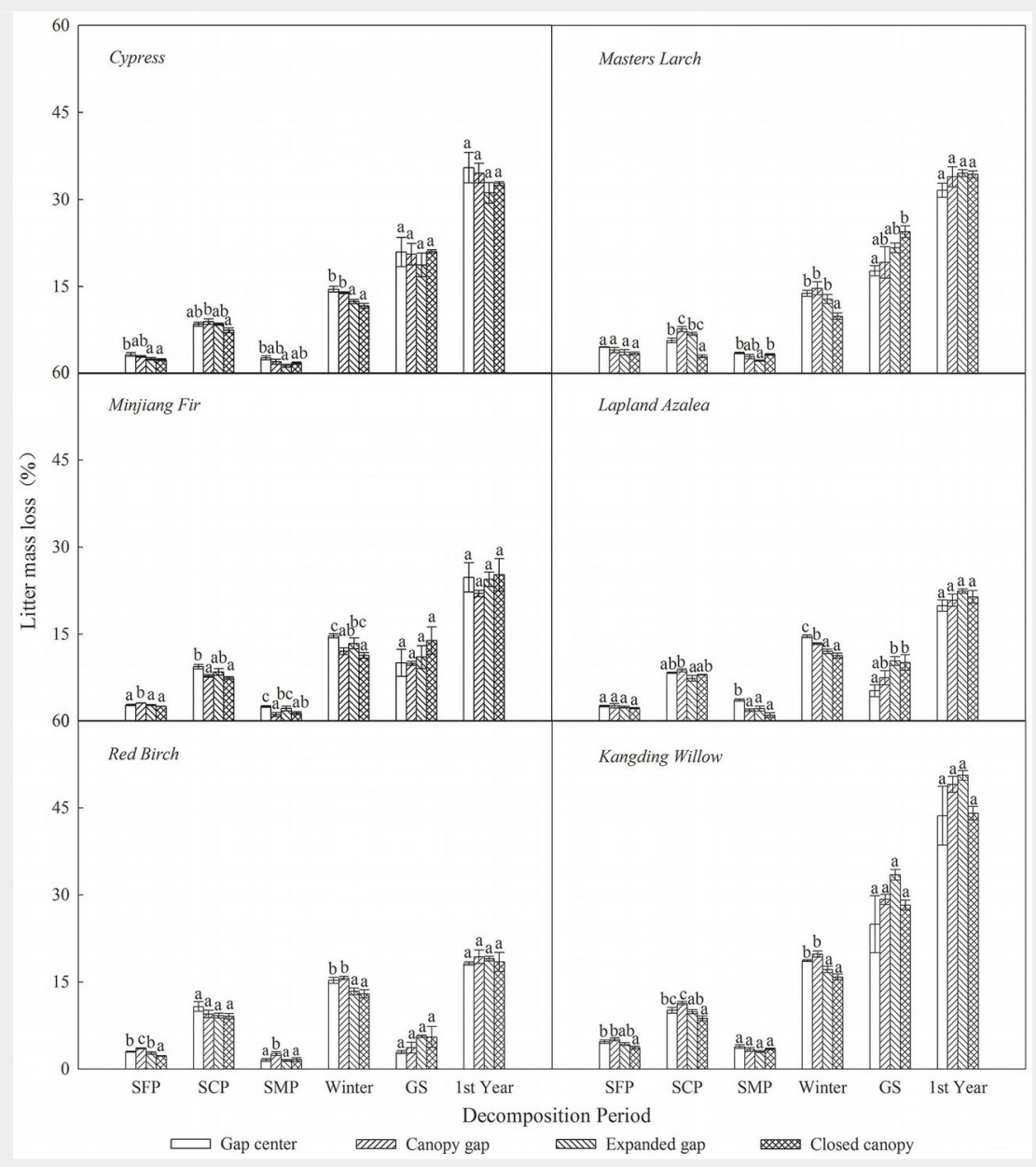

Fig. 4 - Litter mass loss (\%) of the six types of foliar litter (cypress, Minjiang fir, Masters larch, red birch, Kangding willow, Lapland azalea) at the four gap positions (gap center, canopy gap, expanded gap, closed canopy) for each decomposition period (SFP: snow formation period; SCP: snow cover period; SMP: snow melt period; Winter: all of winter; GS: growing season; 1 st Year: the fist year of litter decomposition) over the first year of litter decomposition in an alpine Minjiang fir forest. Different lowercase letters indicate significant differences $(P<0.05)$ between different gap positions at the same decomposition period (mean $\pm \mathrm{SE}, \mathrm{n}=3$ ).

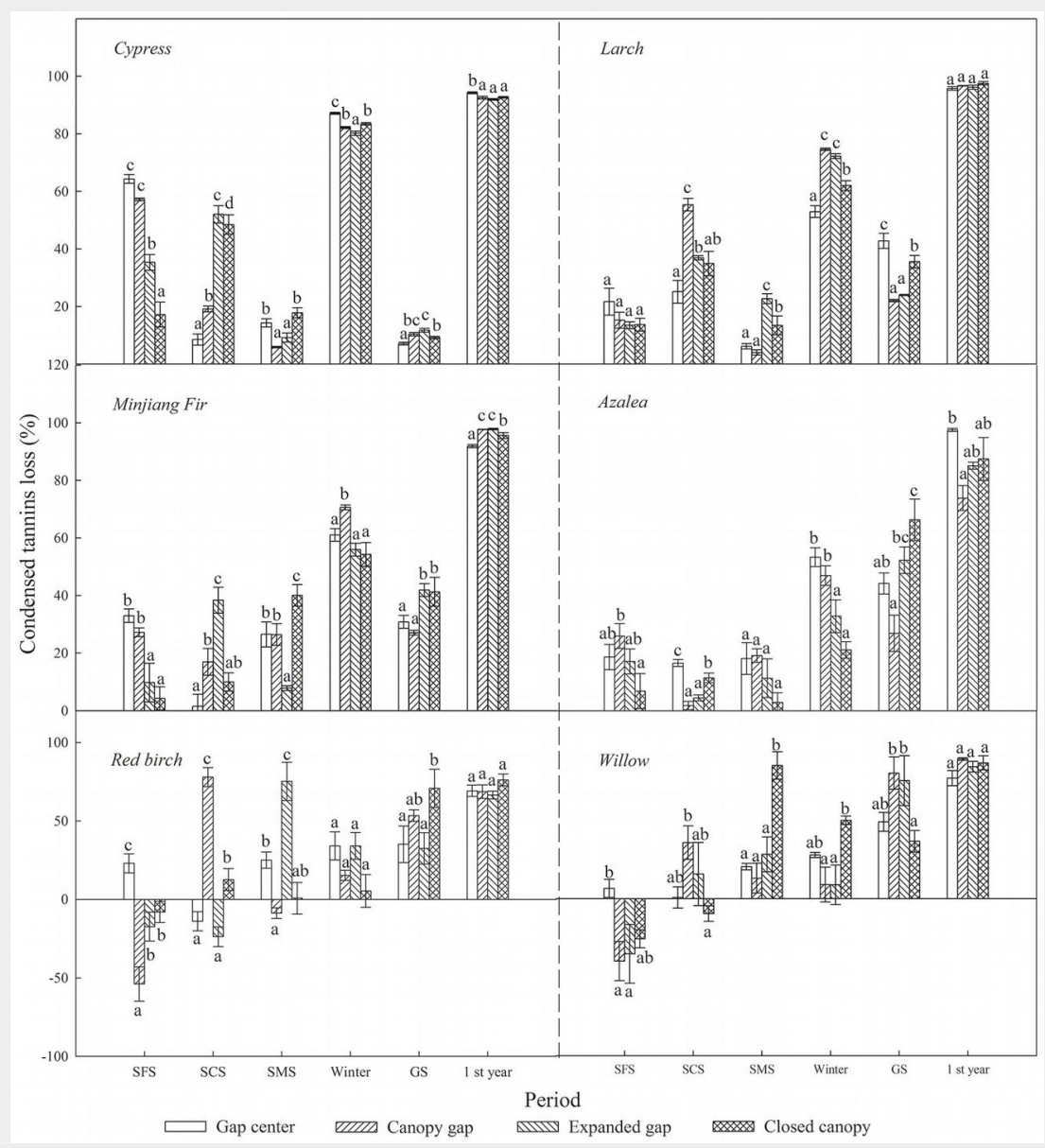

Fig. 5 - Condensed tannins loss (\%) from the six types of foliar litter (cypress, Minjiang fir, Masters larch, red birch, Kangding willow, Lapland azalea) at the four gap positions (gap center, canopy gap, expanded gap, closed canopy) for each decomposition period (SFP: snow formation period; SCP: snow cover period; SMP: snow melt period; Winter: all of winter; GS: growing season; 1 st Year: the fist year of litter decomposition) over the first year of litter decomposition in an alpine Minjiang fir forest. Different lowercase letters indicate significant differences $(P<0.05)$ between different gap positions for the same decomposition period (mean $\pm \mathrm{SE}, \mathrm{n}=3$ ). 
and during the growing season. In the snow formation period, all of the studied litter showed higher losses of CTs in the gap center and in the canopy gap, with the exception of the red birch and Kangding willow litters, which only exhibited a decline in CTs in the gap center and an increase in the other gap positions. Except Lapland azalea, all other types of foliar litter exhibited the greatest losses of CTs in the canopy gaps or in the expanded gaps during the snow cover period. In the snow melt period, most foliar litter showed the greatest declines in CTs in the expanded gap or in the closed canopy, although the Lapland azalea litter did not show a significant decrease in CTs during this period. Overall, there were greater losses of CTs throughout the winter from litter that was primarily located in the gap centers and in the canopy gaps as compared with that in the expanded gaps and in the closed canopies. In contrast, the pattern of CTs loss was inconsistent among species throughout the growing season. The litters of Minjiang fir, Lapland azalea and red birch showed the greatest loss of CTs in the closed canopy, but cypress and Kangding willow exhibited greater losses of CTs in the canopy gap and in the expanded gap, while Masters larch showed the opposite pattern. There were non-significant differences in the one-year loss of CTs among the litters in the different gap positions, although the cypress and Lapland azalea litters showed greater losses in the gap center.

\section{Factors influencing the loss of} condensed tannins from litter

Based on the stepwise multiple regression correlations (Tab. 4), CTs losses were more strongly correlated with the initial chemical qualities of the litter than with the temperatures of each decomposition period, and all of these correlations were positive. The daily mean temperature was only correlated with CTs losses during the snow cover period, whereas the positive accumulated temperature and frequency of soil freeze-thaw cycles were both correlated with CTs losses during the snow formation period. Among the chemical qualities of the litter, the initial CTs, $\mathrm{N}$ and cellulose contents were correlated with CTs losses during the entire winter, the snow formation period and the first year. The initial CTs, P and cellulose contents and the N/P ratio were correlated with CTs losses throughout the entire winter, but the initial cellulose content and the N/P and lignin/ $\mathrm{N}$ ratios were correlated with CTs losses during the first year. In addition, the initial $P$ content and the N/P ratio exhibited strong correlations with CTs losses throughout the winter and the first year, respectively.

\section{Discussion}

Forest gaps and their surrounding crown canopies affect the snowpack depth in winter, as well as regulate the tempera- ture, precipitation and solar radiation in the growing season (Wu et al. 2014b), which may influence litter decomposition through intense leaching, freeze-thaw cycling and subsequently regulate and control CTs losses. Our results revealed that the loss of litter CTs was significantly affected by the gap position, species, season and their interactions over the first year of litter decomposition (Tab. 3).

As CTs molecules are complex and energetically costly to synthesize, their widespread occurrence and abundance suggest that they play an important role in the function and degradation of foliar litter and may slow the litter decomposition process (Zhou et al. 2012). Throughout the experimental period, all six types of foliar litter exhibited high losses of CTs, and the differences among the different gap positions were not significant, except in the gap center; Minjiang fir showed a lower loss of CTs, while cypress and Lapland azalea exhibited a distinctively increased loss (Fig. 5). Such result suggests that the interspecific differences shown in Tab. 1 had a strong influence on CTs losses (Berg 2000, Berg \& McClaugherty 2014). Indeed, this is consistent with the results of the stepwise regression analysis that proved a strong correlation between CTs losses and the chemical characteristics of the initial substrate (N/P, lignin/ $N$, cellulose - Tab. 4). Leaching is an important mechanism driving the removal of CTs from litter, especially in the early decomposition period (Hernes et al. 2001, Zhou et al. 2012). The fresh litter of late autumn (Don \& Kalbitz 2005 ) is characterized by relatively abundant available nutrients, and the rapid loss of soluble and low-molecular-weight compounds such as methanol-extractable CTs (Berg 2000, Lemma et al. 2007) accounts for the rapid losses of CTs from all of the litters during the snow formation period in our study. During this period, strong eluviation occasionally occurred as a result of rain followed by rapid, deep snow coverage in the gap center, which caused a fast decrease in temperature, and this process might promote CTs leaching and microbial assimilation (Wu et al. 2014a, 2014b) that would cause a greater loss of CTs from all of the litters in the gap center.

With the accumulation of snowfall and the low-temperature environment during the snow cover period, there were significant differences in the conditions for degradation among the different gap positions (Wu et al. 2014b). Three types of conifer foliar litter showed greater CTs losses, which was consistent with previous results that indicated that snow cover can increase litter decomposition (Wu et al. 2010, 2014a, Zhu et al. 2012), but degradation or oxidation caused by microorganisms also plays an important role in litter CTs losses (Zhou et al. 2012). For example, Enterobacter has the capacity to degrade CTs, and the actinomycete Debaryomyces hansenii can produce tannin-degrading en- zymes (Bhat et al. 1998). Thus, both enzymatic breakdown and the complexation of CTs can contribute to the loss of the extractable CTs in litter under snow coverage (Coulis et al. 2009). The deep snow conditions in the gap center were favorable for CTs biodegradation because of the relatively warmer and wetter conditions, which supported a higher variety and activity of organisms (Uchida et al. 2005, Bokhorst et al. 2013, Wu et al. 2014b). However, the intense freeze-thaw mechanical disruptions under the closed canopy were favorable to the complexation of CTs because they caused the production of additional proteins and cell-wall polysaccharides (Haase \& Wantzen 2008). Nonetheless, all of the foliar litter in our study (except for the Lapland azalea litter) exhibited higher CTs losses in the canopy gap and in the expanded gap, which implied that the combined action of the freeze-thaw mechanical disruptions and biodegradation could promote CTs losses during the snow cover period.

Along with increasing temperature, the intense leaching and frequent freeze-thaw cycles caused by melting snow play an important role in litter decomposition during the snow melt period (Wu et al. 2010, 2014a). Compared with the CTs in the gap center and in the canopy gap, the CTs of all of the foliar litter in the expanded gap and under the closed canopy exhibited greater losses during the snow melt period, which might have resulted from the slow though continuous leaching caused by the melting of sheltered snow that escaped solar radiation under the canopy crown. In addition, the increased moisture, which is beneficial to microbial activity, also led to the biodegradation of the CTs (Haase \& Wantzen 2008, Hicks Pries et al. 2013).

The Growing season, which is characterized by warmer temperatures and sufficient moisture, is beneficial to the recovery of CTs decomposers (Coulis et al. 2009), especially in the readily available litter of broadleaved trees (Berg \& McClaugherty 2014). Therefore, the litter of all three types of broadleaved trees exhibited relatively higher losses of CTs during the growing season than in winter. Due to the extreme decomposition environment resulting from greater sunlight exposure, precipitation and more rapid evaporation in the gap center (Ritter et al. 2005), there could have been adverse effects on the loss of CTs. Comparatively, the combination of more suitable environmental conditions for microbial assimilation and complexation might contribute to a greater loss of CTs under the closed canopy and in the expanded gap, which would be consistent with our results.

In addition, all six types of foliar litter exhibited continuously high losses of CTs (70.18\% to $96.57 \%$ ) throughout the study, with the conifers litters showing a greater CTs loss (92.87\% to $96.57 \%$ ) than the broadleaved trees litters ( $70.18 \%$ to $85.98 \%$ ) 
(Tab. 1). In our study, only the methanolextractable CTs fraction was studied, while that of the bound CTs was not analyzed. In this context, our results the the highly extractable CTs losses are consistent with those of previous studies that showed that the extractable phenolics and tannins decreased along with litter decomposition (Schofield et al. 1998). The CTs losses in the conifers litter might largely depend on the mechanical disruptions caused by the freeze-thaw cycle and leaching, which would result in a greater loss of CTs from conifers litter during the winter. In addition, due to the higher amounts of easily leachable CTs remaining in conifers litter (as it was less decomposed in winter), the higher litter CTs loss might also might be depended on changes in litter quality during the decomposition process. However, the broadleaved trees litter CTs losses might largely depend on chemical modification by microbial assimilation that is influenced by temperature and moisture conditions, which would result in a greater loss of CTs from broadleaved trees litters CTs loss during the growing season. In addition to environmental factors, these variations may not only be caused by the significant differences in the initial substrate among the species, but also by changes in litter quality during decomposition (Berg \& McClaugherty 2014).

\section{Conclusions}

This study describes the decomposition dynamics of methanol-extractable CTs in relation to forest gap and season in an alpine Minjiang fir forest. Over the first year of decomposition, all six types of foliar litter experienced high CTs losses, with values ranging from $70.18 \%$ to $96.67 \%$. The gap center exhibited higher litter CTs losses over the whole year compared with the other gap positions. Forest gaps accelerated litter CTs losses in the winter but inhibited CTs losses in the growing season, which showed significant seasonal differences in litter CTs decomposition. Additionally, the litter of conifers showed greater CTs losses in winter, especially during the snow formation period, whereas the litter of broadleaved trees exhibited greater CTs losses in the growing season. Our results suggested that the formation of forest gaps would promote litter CTs losses in the winter, but retard CTs losses in the growing season in the alpine Minjiang fir forest. Furthermore, they also indicate that the predicted reduction in snow depth resulting from winter warming or the loss of forest gaps caused by forest regeneration will inhibit the decomposition of litter CTs in alpine forest ecosystems, thus slowing the soil carbon sequestration from foliar litter in cold biomes.

\section{Acknowledgements}

We are very grateful to Wei He for assistance with the laboratory analyses. This project was supported by the National Nat- ural Science Foundation of China (Project no. 31170423 and 31270498), the National Key Technologies $R$ and $D$ Program (2011BAC09B05), the Sichuan Excellent Youth Science and Technology Foundation (2012JQ0008, 2012JQ0059) and the special Funding of the China Postdoctoral Science Foundation (2012T50782).

\section{References}

Baptist F, Yoccoz NG, Choler P (2010). Direct and indirect control by snow cover over decomposition in alpine tundra along a snowmelt gradient. Plant Soil 328: 397-410. - doi: 10.1007/s111 04-009-0119-6

Batty LC, Younger PL (2007). The effect of pH on plant litter decomposition and metal cycling in wetland mesocosms supplied with mine drainage. Chemosphere 66:158-164. - doi: 10.1016/j. chemosphere.2006.05.039

Berg B (2000). Litter decomposition and organic matter turnover in northern forest soils. Forest ecology and Management 133: 13-22. - doi: 10.1016/S0378-1127(99)00294-7

Berg B, McClaugherty C (2014). Plant litter: decomposition, humus formation, carbon sequestration ( $3^{\text {rd }}$ edn). Springer-Verlag, Berlin, Germany, pp. 35-107.

Bhat TK, Singh B, Sharma OP (1998). Microbial degradation of tannins-a current perspective. Biodegradation 9: 343-357. - doi: 10.1023/A:1008 397506963

Bokhorst S, Metcalfe DB, Wardle DA (2013). Reduction in snow depth negatively affects decomposers but impact on decomposition rates is substrate dependent. Soil Biology and Biochemistry 62: 157-164. - doi: 10.1016/j.soil bio.2013.03.016

Coulis $M$, Hättenschwiler $S$, Rapior $S$, Coq S (2009). The fate of condensed tannins during litter consumption by soil animals. Soil Biology and Biochemistry 41: 2573-2578. - doi: 10.1016/ j.soilbio.2009.09.022

De Colmenares NG, Ramírez-Martínez JR, Aldana JO, Ramos-Niño ME, Clifford MN, Pékerar S, Méndez B (1998). Isolation, characterisation and determination of biological activity of coffee proanthocyanidins. Journal of the Science of Food and Agriculture 77: 368-372. - doi: 10.1002/(SICI)1097-0010(199807)77:3<368::AIDJSFA52>3.0.CO;2-V

Don A, Kalbitz K (2005). Amounts and degradability of dissolved organic carbon from foliar litter at different decomposition stages. Soil Biology and Biochemistry 37: 2171-2179. - doi: 10.1016/j.soilbio.2005.03.019

Haase K, Wantzen KM (2008). Analysis and decomposition of condensed tannins in tree leaves. Environmental Chemistry Letters 6: 7175. - doi: 10.1007/s10311-008-0140-7

Hagerman AE, Butler LG (1989). Choosing appropriate methods and standards for assaying tannin. Journal of Chemical Ecology 15: 1795-1810. doi: $10.1007 / B F 01012267$

Hagerman $A E$, Riedl KM, Jones GA, Sovik KN, Ritchard NT, Hartzfeld PW, Riechel TL (1998). High molecular weight plant polyphenolics (tannins) as biological antioxidants. Journal of Agricultural and Food Chemistry 46: 1887-1892. -doi: 10.1021/jf970975b

Hartzfeld PW, Forkner R, Hunter MD, Hagerman
AE (2002). Determination of hydrolyzable tannins (gallotannins and ellagitannins) after reaction with potassium iodate. Journal of Agricultural and Food Chemistry 50: 1785-1790. - doi: 10.1021/jfo111155

He W, Wu F, Zhang D, Yang W, Tan B, Zhao Y, Wu $Q$ (2015). The effects of forest gaps on cellulose degradation in the foliar litter of two shrub species in an alpine fir forest. Plant and Soil 114. - doi: 10.1007/s11104-015-2479-4

Heil M, Baumann B, Andary C, Linsenmair EK, McKey D (2002). Extraction and quantification of "condensed tannins" a measure of plant anti-herbivore defence? Revisiting an old problem. Naturwissenschaften 89: 519-524. - doi: 10.1007/s00114-002-0366-3

Hernes PJ, Benner R, Cowie GL, Goñi MA, Bergamaschi BA, Hedges Jl (2001). Tannin diagenesis in mangrove leaves from a tropical estuary: a novel molecular approach. Geochimica et Cosmochimica Acta 65: 3109-3122. - doi: 10.1016/ So016-7037(01)00641-X

Hicks Pries CE, Schuur EAG, Vogel JG, Natali SM (2013). Moisture drives surface decomposition in thawing tundra. Journal of Geophysical Research: Biogeosciences 118: 1133-1143. - doi: 10.1002/jgrg.20089

Konestabo HS, Michelsen A, Holmstrup M (2007). Responses of springtail and mite populations to prolonged periods of soil freeze-thaw cycles in a sub-arctic ecosystem. Applied Soil Ecology 36: 136-146. - doi: 10.1016/j.apsoil.20 07.01.003

Kraus TE, Dahlgren RA, Zasoski RJ (2003). Tannins in nutrient dynamics of forest ecosystems a review. Plant and Soil 256: 41-66. - doi: 10.1023/A:1026206511084

Lemma B, Nilsson I, Kleja DB, Olsson M, Knicker $H$ (2007). Decomposition and substrate quality of leaf litters and fine roots from three exotic plantations and a native forest in the southwestern highlands of Ethiopia. Soil Biology and Biochemistry 39: 2317-2328. - doi: 10.1016/j.soil bio.2007.03.032

Lin YM, Liu JW, Xiang P, Lin P, Ye GF, Da Sternberg LSL (2006). Tannin dynamics of propagules and leaves of Kandelia candel and Bruguiera gymnorrhiza in the Jiulong River Estuary, Fujian, China. Biogeochemistry 78: 343-359. doi: 10.1007/s10533-005-4427-5

Maie N, Pisani O, Jaffé R (2008). Mangrove tannins in aquatic ecosystems: their fate and possible influence on dissolved organic carbon and nitrogen cycling. Limnology and Oceanography 53: 160-171. - doi: 10.4319/lo.2008.53.1.0160 Ni X, Yang W, Li H, Xu L, He J, Tan B, Wu F (2014). The responses of early foliar litter humification to reduced snow cover during winter in an alpine forest. Canadian Journal of Soil Science 94: 453-461. - doi: 10.4141/cjss2013-121

Ni X, Yang W, Tan B, He J, Xu L, Li H, Wu F (2015). Accelerated foliar litter humification in forest gaps: dual feedbacks of carbon sequestration during winter and the growing season in an alpine forest. Geoderma 241: 136-144. - doi: 10.1016/j.geoderma.2014.11.018

O'Connell AM (1997). Decomposition of slash residues in thinned regrowth eucalypt forest in Western Australia. Journal of Applied Ecology 34: 111-122. - doi: 10.2307/2404852

Olsson PQ, Sturm M, Racine CH, Romanovsky V, 
Liston GE (2003). Five stages of the Alaskan Arctic cold season with ecosystem implications. Arctic, Antarctic, and Alpine Research 35: 74-81. - doi: 10.1657/1523-0430(2003)035[0074:FSOTA A]2.0.CO;2

Promis A, Gärtner S, Reif A, Cruz G (2012). Effects of canopy gaps on forest floor vascular and non-vascular plant species composition and diversity in an uneven-aged Nothofagus betuloides forest in Tierra del Fuego, Chile. Community Ecology 13: 145-154. - doi: 10.1556/ComEc. 13.2012.2.3

Ritter E, Dalsgaard L, Einhorn KS (2005). Light, temperature and soil moisture regimes following gap formation in a semi-natural beech-dominated forest in Denmark. Forest Ecology and Management 206: 15-33. - doi: 10.1016/j.foreco. 2004.08.011

Sariyildiz T (2008). Effects of gap-size classes on long-term litter decomposition rates of beech, oak and chestnut species at high elevations in Northeast Turkey. Ecosystems 11: 841-853. - doi: 10.1007/s10021-008-9164-x

Schofield JA, Hagerman AE, Harold A (1998). Loss of tannins and other phenolics from willow leaf litter. Journal of Chemical Ecology 24: 1409-1421. - doi: 10.1023/A:1021287018787

Song $X Z$, Jiang $H$, Zhang $H L$, Yu SQ, Zhou GM, Ma YD, Chang SX (2008). A review on the effects of global environment change on litter decomposition. Acta Ecologica Sinica 28: 4414-4423.

Spies TA, Franklin JF, Klopsch M (1990). Canopy gaps in Douglas-fir forests of the Cascade Mountains. Canadian Journal of Forest Research 20: 649-658. - doi: 10.1139/x90-087
Talbot JM, Yelle DJ, Nowick J, Treseder KK (2012). Litter decay rates are determined by lignin chemistry. Biogeochemistry 108: 279-295. - doi: 10.1007/s10533-011-9599-6

Tan B, Wu FZ, Yang WQ, Liu L, Yu S (2010). Characteristics of soil animal community in the subalpine/alpine forests of western Sichuan during onset of freezing. Acta Ecologica Sinica 30: 9399. - doi: 10.1016/j.chnaes.2010.03.008

Tan B, Wu FZ, Yang WQ, Yang YL, Wang A, Kang LN (2011a). Effects of snowpack removal on the dynamics of winter-time soil temperature, carbon, nitrogen, and phosphorus in alpine forests of west Sichuan. Chinese Journal of Applied Ecology 22: 2553-2559.

Tan B, Wu F, Yang W, Yu S, Liu L, Wang A (2011b). The dynamics pattern of soil carbon and nutrients as soil thawing proceeded in the alpine/subalpine forest. Acta Agriculturae Scandinavica, Section B - Soil Plant Science 61: 670679. - doi: 10.1080/09064710.2010.541489

Uchida M, Mo W, Nakatsubo T, Tsuchiya Y, Horikoshi T, Koizumi H (2005). Microbial activity and litter decomposition under snow cover in a cool-temperate broad-leaved deciduous forest. Agricultural and forest meteorology 134: 102109. - doi: 10.1016/j.agrformet.2005.11.003

Whitmore TC (1989). Canopy gaps and the two major groups of forest trees. Ecology 70: 536538. - doi: 10.2307/1940195

Wu F, Yang W, Zhang J, Deng R (2010). Litter decomposition in two subalpine forests during the freeze-thaw season. Acta Oecologica 36: 135-140. - doi: 10.1016/j.actao.2009.11.002

Wu F, Peng C, Zhu J, Zhang J, Tan B, Yang W (2014a). Impact of changes in freezing and thawing on foliar litter carbon release in alpine/subalpine forests along an altitudinal gradient in the eastern Tibetan Plateau. Biogeosciences Discussions 11: 9539-9564. - doi: 10.5194/bgd-11-9539-2014

Wu Q, Wu F, Yang W, Zhao Y, He W, Tan B (2014b). Foliar litter nitrogen dynamics as affected by forest gap in the alpine forest of Eastern Tibet Plateau. PLoS ONE 9 (5): e97112. doi: 10.1371/journal.pone.0097112

Zhang LH, Ye GF, Lin YM, Zhou HC, Zeng Q (2009). Seasonal changes in tannin and nitrogen contents of Casuarina equisetifolia branchlets. Journal of Zhejiang University Science B 10: 103-111. - doi: 10.1631/jzus.B0820217

Zhou HC, Tam NFY, Lin YM, Wei SD, Li YY (2012). Changes of condensed tannins during decomposition of leaves of Kandelia obovata in a subtropical mangrove swamp in China. Soil Biology and Biochemistry 44: 113-121. - doi: 10.1016/j.soil bio.2011.09.015

Zhu J, He X, Wu F, Yang W (2012). Decomposition of Abies faxoniana litter varies with freeze-thaw stages and altitudes in subalpine/alpine forests of southwest China. Scandinavian Journal of Forest Research 27: 586-596. - doi: 10.1080/028 27581.2012.670726

Zhu J, Yang W, He X (2013). Temporal dynamics of abiotic and biotic factors on leaf litter of three plant species in relation to decomposition rate along a subalpine elevation gradient. PLOS ONE 8 (4): e62073. - doi: 10.1371/journal. pone.0062073 